UDK 632.953.2

\title{
SYNTHESIS AND RESEARCH INTO ANTICORROSION AND BACTERICIDE PROPERTIES OF CHLORINE-CONTAINING IMIDAZOLINE COMPLEXES OF DISTILLATED NATURAL OIL ACIDS
}

\author{
N.A. Mammadova, S.A. Mamedkhanova \\ Azerbaijan State Oil and Industry Universityj \\ 20, Azadliq ave., AZ 1010, Baku; e-mail: n.a.mamedova@inbox.ru
}

\begin{abstract}
The imidazoline complexes obtained by reaction of distillated natural oil acids (NOA) with diethylenetriamin (DETA) have been synthesized. The chlorine-containing complexes of NOA were synthesized on the basis of obtained imidazoline, their physio-chemical characteristics and structure proved true by IR-and NMR spectrums data. The properties of chlorine-containing imidazoline complexes of $\mathrm{NOA}$ as inhibitors of $\mathrm{H}_{2} \mathrm{~S}$ - and $\mathrm{CO}_{2-}^{-}$, bio-corrosion have been studied. The tests showed that $\mathrm{CO}_{2}$ - and $\mathrm{H}_{2} \mathrm{~S}$ - corrosions of the complexes protect a metal surface up to 95$100 \%$. The effect of the influence of synthesized complexes on life activity of sulphate-reducing bacteriums (SRB) in three concentrations at $30^{\circ} \mathrm{C}$ temperature during 15 days revealed that even at low concentrations these complexes may be recommended as high-effective inhibitors to oppose metal biocorrosion.
\end{abstract}

Keywords: corrosion, biodamage, distillated natural oil acids, imidazolines, inhibitors, sulphatereducing bacteriums

The use of oilfield equipment is accompanied by various difficulties arising from biostate of charge, carbonic acid and hydrogen sulphide corrosion [1-3], etc. To control this effect, experts apply inhibitors of corrosion based on the basis of organic compounds with atoms of nitrogen, sulphur, oxygen and double bonds to thus favor absorption on metal surface [4]. It revealed that some nitrongen-containing derivatives of oil acids are $\mathrm{CO}_{2}$ - corrosion $[5,6]$.

The article deals with the results of investigations on working out $\mathrm{CO}_{2}-\mathrm{H}_{2} \mathrm{O}$-and bio-corrosion on the basis of imidazoline chlorine-containing derivatives of natural oil acids (NOA) with diethylenetriamin (DETA).

\section{EXPERIMENTAL PART}

To synthesize chloroderivatives of NOA, the natural oil acids of "Karvan-L" diethylentriamin (DETA) (company "Kazanorgsyntensi," Russia), allyl chloride (Moscow company "Component Reactant", Russia) were used while the propyl chloroester of NOA was synthesized by authors of the article. The all reagents were used without any purification.

The structures of the obtained complex compounds were proved out by IR spectral analysis. Also, IR-spectrum of samples were registered on Fourier microscope LUMOS (firm BRUKER Germany) within wave frequency $600-4000 \mathrm{sm}^{-1}$.
$\mathrm{NMR}^{1} \mathrm{H}$ spectrums were registered on Bruker Avance (Germany) II+300 (Ultra Shield тм Magnet) $300 \mathrm{MHz}$, solvent$\mathrm{CD}_{3} \mathrm{COOCD}_{3}$, chemical shifts are cited conformably TMS.

Some physical-chemical indices of complex compounds obtained on the basis of Baku natural oil acids were established. Crystallization temperature was established by standard - 5066-91, index of refraction $n_{D}^{20}$ on refractometer IRF-22 N700060, relative density $\left(d_{4}^{20}\right)$ by standard 3900-2000.

Synthesis of imidazoline of NOA. The 0.1 mol of NOA was put in a round-bottomfour-neck flask supplied with a mixer, 
thermometer, opposite cooler and dropping funnel, then mixed and heated up to $80-90^{\circ} \mathrm{C}$ temperature and DETA was discharged by means of dropping funnel within 1.5 hours. The initial compounds were given by mole correlation equal 1:1. During synthesis process the temperature was raised up to $240^{\circ} \mathrm{C}$ and maintained for 3.5 hours. It should be noted that at $130^{\circ} \mathrm{C}$ temperature the amino amid of NOA was obtained as intermediate compound. Mixing continued until the temperature fell to $50-60^{\circ} \mathrm{C}$. It revealed that through the synthesis of imidazoline derivative of NOA on the basis of DETA a greater quantity of solid substances were formed with yield up to $90 \%$ mas synthesis of the chloride complex $\mathrm{N}$-allyl imidazoline NOA (chloride of complex ).

Synthesis of the chloride of $\mathrm{N}$-allyl imidazoline complex of NOA (Chloride of complex I). The imidazaline of NOA and allylchloride were used as initial compounds in mol correlation $1: 1$. The reaction proceeded at $40-50^{\circ} \mathrm{C}$ by mixing within 3-3.5 hours in the presence of solvent isopropyl alcohol. A yield of chlorine-containing imidazoline derivative of NOA is $95 \%$ mass.

Synthesis of chloride complex $N$ propyl naphtenate imidazoline of NOA (Chloride of complex II). The reaction proceeded on the basis of above-mentioned methods but at a temperature of $80-90^{\circ} \mathrm{C}$ (a boiling point of isopropyl alcohol) during 3 hours. The imidazoline of NOA and propylchloride ester of NOA were taken as initial compounds. Complex compounds obtained with $97 \%$ mass of yield.

\section{RESULTS AND THEIR DISCUSSION}

The synthesis of imidazoline of NOA proceeds by the interaction of NOA with DETA according to the scheme below:

$$
\begin{aligned}
& \mathrm{R}-\mathrm{C}=\mathrm{OH}+\mathrm{H}_{2} \mathrm{~N}-\mathrm{CH}_{2}-\mathrm{CH}_{2}-\mathrm{NH}-\mathrm{CH}_{2}-\mathrm{CH}_{2}-\mathrm{NH}_{2} \underset{-\mathrm{H}_{2} \mathrm{O}}{\stackrel{130^{\circ}}{\longrightarrow}} \\
& \longrightarrow \mathrm{R}-\mathrm{C}-\mathrm{O}
\end{aligned}
$$

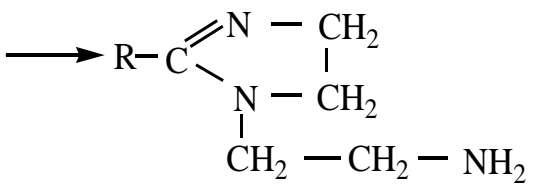

where, $\mathrm{R}$-mixture of alkyl, izoalkyl and naphtenic radicals

The synthesis of chlorine-containing imidazoline of NOA with chlorine-containing imidazoline complexes of distillated natural oil products according to the scheme below: acids proceeds by the interaction of

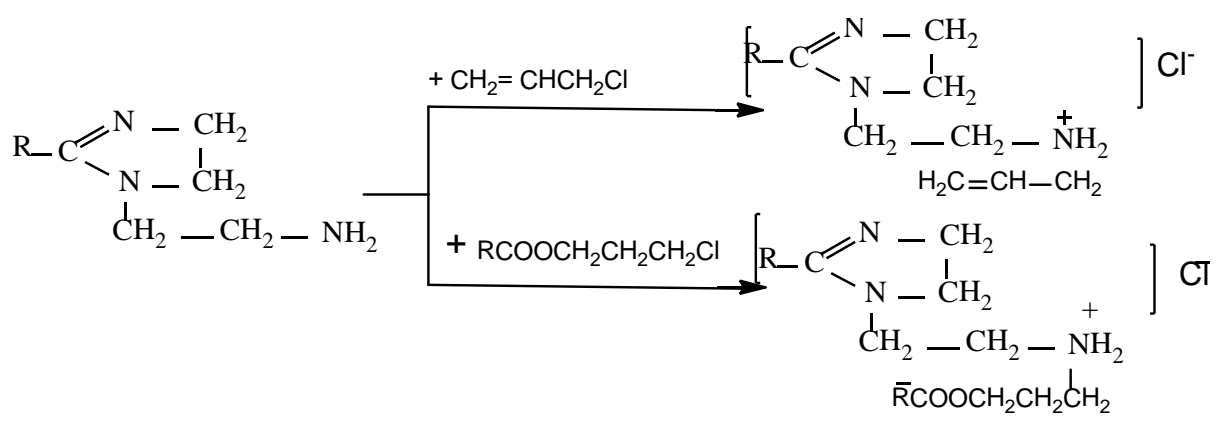

Note that the synthesized products were identified by IR and ${ }^{1} \mathrm{H}$ NMR- spectroscopy method. These are followed by bands of absorption in the IR-spectrum 
imidazoline of NOA: deformative (1552,1607 $\mathrm{sm}^{-1}$ ) and valence $\left(3279 \mathrm{sm}^{-1}\right)$ vibrations of $\mathrm{N}$ $\mathrm{H}$ bond in group $\mathrm{NH}_{2}$, deformative vibrations $\left(2923,1454,2813,2853,1375 \mathrm{sm}^{-1}\right) \mathrm{C}-\mathrm{H}$ bond of $\mathrm{CH}_{2}, \mathrm{CH}_{3}$ - groups, deformative vibrations $\left(1010,1138,1272 \mathrm{sm}^{-1}\right) \mathrm{C}-\mathrm{N}$ bond and deformative vibrations $\left(1655 \mathrm{sm}^{-1}\right) \mathrm{C}=\mathrm{N}$ bond (Fig1).

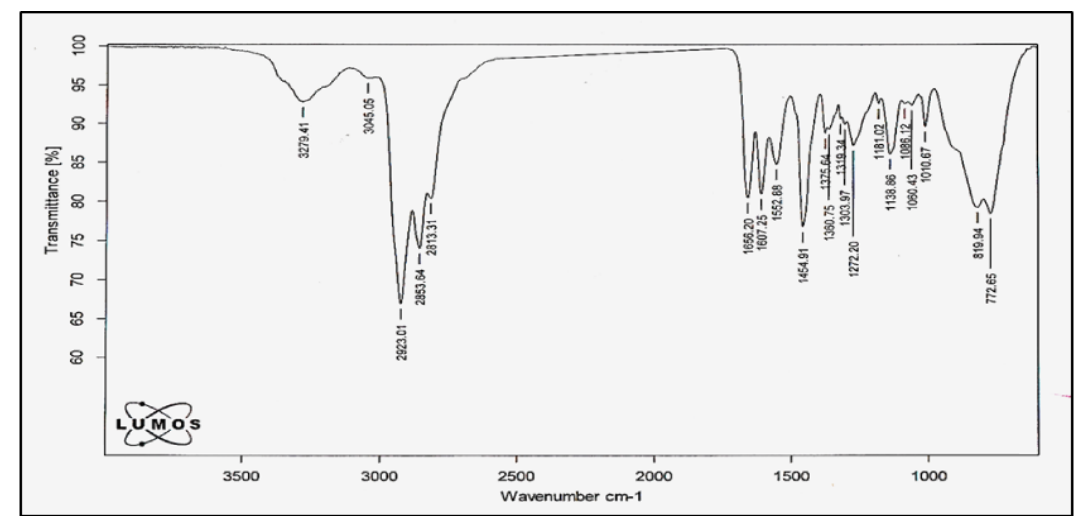

Fig 1. IR Spectrum of imidazoline of NOA

Resonance signals inherent in NOA $\left(\mathrm{CH}_{3}, \mathrm{CH}_{2}\right.$, aromatic and naphthenic cycles) are observed in a sample of imidazoline of NOA of the proton spectrum. The chemical shifts at $\delta=0.90$ and 1.35 m.d. correspond to $\mathrm{CH}_{3}$ and $\mathrm{CH}_{2}$ resonance signals for alkyl groups, in the range $\delta=1.5-1.8$ m.d. for the naphthenic ring. The resonance signals corresponding to amidoamines, in the magnetic field region $\delta=2.3-3.10 \mathrm{~m}$.d, are characteristic for - $\mathrm{CH}_{2}-\mathrm{NH}_{2}$ groups, and at $\delta$ = 2.0-2.2 m.d. is characteristic for $\mathrm{NH}_{2}$ groups, at $\delta=3.30-3.60$ m.d. identified by signals related to the ethyl groups (fig.2).

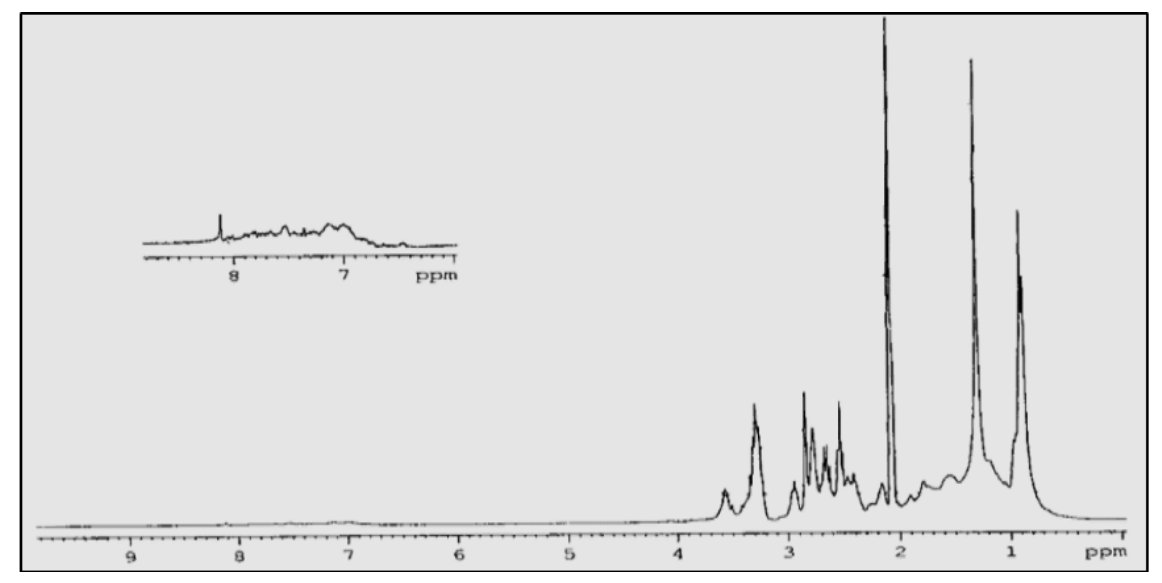

Fig 2. ${ }^{1} \mathrm{H}-\mathrm{NMR}$ of imidazoline of NOA

Next comes the following band absorption in IR-spectrum Chloride of complex I: valence (2870, 2925, $\left.2966 \mathrm{sm}^{-1}\right)$ and deformative vibrations $\left(1377,1460 \mathrm{sm}^{-1}\right.$ ) of $\mathrm{C}-\mathrm{H}$ bond of $\mathrm{CH}_{2}, \mathrm{CH}_{3}$ groups; deformation (951, $1549 \mathrm{sm}^{-}$ $\left.{ }^{1}\right)$ vibrations of $\mathrm{N}-\mathrm{H}$ bond in groups $\mathrm{NH}_{2}$; valence(1105, 1129, $1160 \mathrm{sm}^{-1}$ )vibrations $\mathrm{C}-\mathrm{N}$ bond, valence (1645 $\left.\mathrm{sm}^{-1}\right)$ vibrations $\mathrm{C}=\mathrm{N}$ bond, deformative (1404 sm $\mathrm{sm}^{-1}$ ) vibrations of $\mathrm{CH}_{2}$ group wide band $\mathrm{N}^{+}$, deformativ (922, $977 \mathrm{sm}^{-1}$ ) vibrations of $\mathrm{C}=\mathrm{C}$ bond in $\alpha$-position and valence (3048 sm${ }^{-1}$ ) vibrations of $=\mathrm{CH}_{2}$ groups(fig3). 


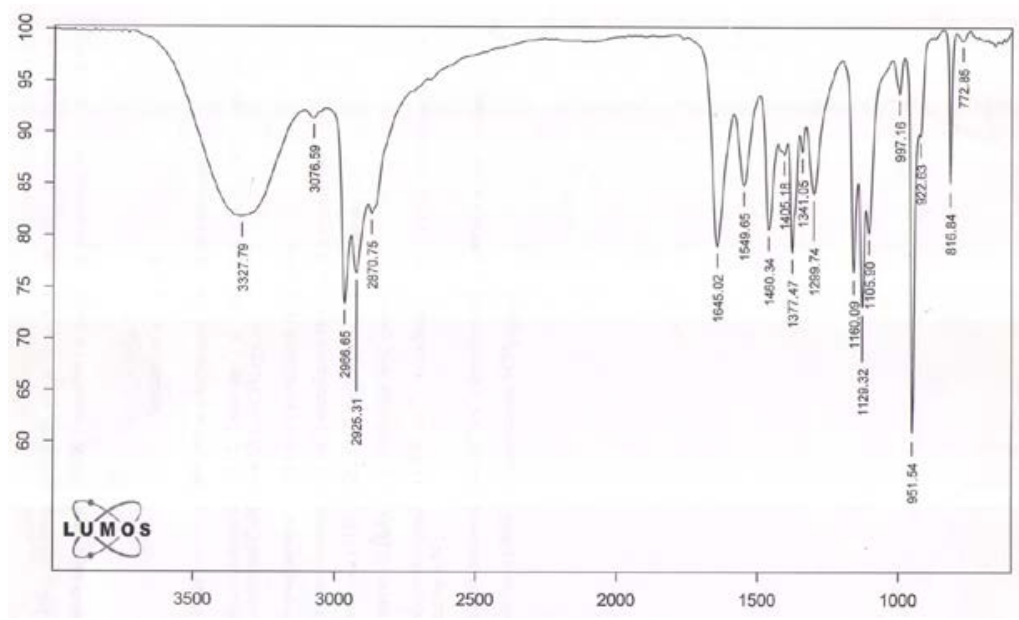

Fig 3. IR Spectrum of chloride of complex I

There is a band absorption in IR- $\left(1378 \mathrm{sm}^{-1}\right)$ for $\mathrm{C}=\mathrm{O}$ bond of ester and (1647 spectrum chloride of complex II as follows: pendular $\left(724 \mathrm{sm}^{-1}\right)$ oscillations of $\mathrm{C}-\mathrm{H}$ bond of $\mathrm{CH}_{2}$, deformative $\left(1457,1460 \mathrm{sm}^{-1}\right)$ and valence(2923, $2955 \mathrm{sm}^{-1}$ ) vibrations of $\mathrm{C}-\mathrm{H}$ bond of $\mathrm{CH}_{2}$ group, deformative(2923,2955 $\mathrm{sm}^{-1}$ ) vibrations of $\mathrm{C}-\mathrm{H}$ bond of $\mathrm{CH}_{3}$; valence $\mathrm{sm}^{-1}$ ) vibrations of $\mathrm{C}-\mathrm{N}$ bond, deformation (952 $\mathrm{sm}^{-1}$ ) vibrations of $\mathrm{N}-\mathrm{H}$ bond in groups $\mathrm{NH}_{2}$; valence $\left(1129,1160 \mathrm{sm}^{-1}\right)$ vibrations C$\mathrm{N}$ bond, deformative (1547 $\mathrm{sm}^{-1}$ ) and valence (3291 sm ${ }^{-1}$ )vibrations of $\mathrm{C}-\mathrm{N}$ bound $\mathrm{NH}^{+}$, $\mathrm{NH}, \mathrm{NH}_{2}$ groups (fig 4).

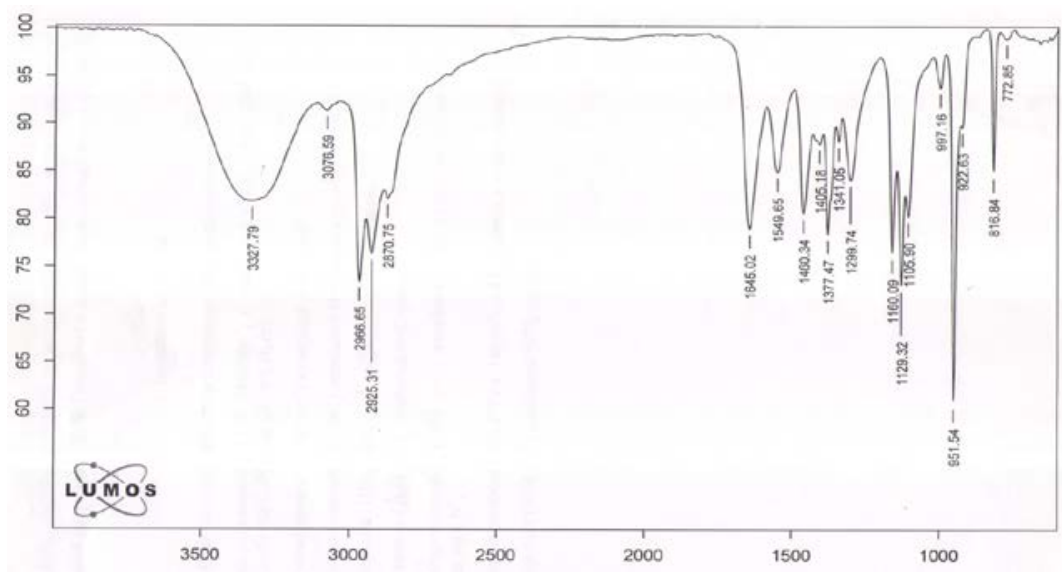

Fig 4. IR Spectrum chloride of complex II

Physio-chemical parameters of synthesized chlorine-containing imidazoline complexes are shown in Table 1.

Table 1. Physio-chemical parameters of synthesized products

\begin{tabular}{|c|c|c|c|c|c|}
\hline Name of complex compounds & $\begin{array}{c}\text { Correlation } \\
\text { of } \\
\text { complexes }\end{array}$ & $\begin{array}{c}d_{4}^{20} \\
\mathrm{kq} / \mathrm{m}^{3}\end{array}$ & $n_{D}^{20}$ & $\begin{array}{c}\text { Freezing } \\
\text { point, } \\
{ }^{0} \mathrm{C}\end{array}$ & $\begin{array}{l}\text { Yield , } \\
\%\end{array}$ \\
\hline Imidazoline of NOA & $1: 1$ & 1086 & 1.2340 & 17 & 89.9 \\
\hline $\begin{array}{c}\text { Chloride of complex N-allyl } \\
\text { imidazoline of NOA } \\
\text { (Chloride of complex I) }\end{array}$ & $1: 1$ & 1105 & 1.2160 & - & 95 \\
\hline
\end{tabular}




\begin{tabular}{|c|c|c|c|c|c|}
\hline $\begin{array}{c}\text { Chloride complex N-propyl } \\
\text { naphtenate imidazoline of NOA } \\
\text { (Chloride of complex II). }\end{array}$ & $1: 1$ & 1045 & 1.1885 & - & 97 \\
\hline
\end{tabular}

Antibacterial properties of synthesized imidazoline complexes of NOA. The influence of synthesized chlorine-containing imidazolin complexes of NOA on the vital activity of SRB. SRB's 1143 strain was tested. Sterilized test tubes with $20 \mathrm{ml}$ volume were used in the experiment [6]. Bactericidal effect of the reagents mainly manifested itself during 15 days and then examined on the basis of calculation of the generated $\mathrm{H}_{2} \mathrm{~S}$ content. Note that $\mathrm{H}_{2} \mathrm{~S}$ was determined iodometrically. The water was chosen as a solvent for the complexes which dissolved well to generate transparent solutions with $1 \%$ concentration. SRB are obligate anaerobic bacteriums that dissimilate sulphates into hydrogen sulfide $\left(\mathrm{H}_{2} \mathrm{~S}\right)$. Medium "Postgate - B" is more effective nutrient medium for SRB development. The composition of nutrient medium "Postgate -B" is shown in Table 2. The $\mathrm{pH}$ of the medium should be within 7.07.5.

Table 2. Composition of feeding medium "Postgate-B"

\begin{tabular}{|l|l|c|c|l|c|}
\hline № & \multicolumn{1}{|c|}{ Name of compounds } & Gramme & № & Name of compounds & Gramme \\
\hline 1 & $\begin{array}{l}\text { Potassium salt of } \\
\text { dihydrophosphate acid }\end{array}$ & 0.5 & 4 & Magnesium sulphate & 2.0 \\
\hline 2 & Ammonia chloride & 1.0 & 5 & Sodium lactate & 3.5 \\
\hline 3 & Calcium sulphate & 1.0 & 6 & Sodium chloride & 2.0 \\
\hline
\end{tabular}

Special additives were put into the nutrient medium for the development of SRB. These additions have the following composition: $5 \%$ solution of $\mathrm{FeSO}_{4} \cdot 7 \mathrm{H}_{2} \mathrm{O}$ in $2 \%$ solution of hydrochloric acid, $5 \%$ aqueous solution of $\mathrm{NaHCO}_{3}, 1 \%$ of crystalline
$\mathrm{Na}_{2} \mathrm{~S} \cdot 9 \mathrm{H}_{2} \mathrm{O}$ is in the $1 \%$ aqueous solution of $\mathrm{Na}_{2} \mathrm{CO}_{3}$.

The influence of the dependence of chlorine-containing imidazoline complexes of NOA at concentrations of $15,75,150$ on the growth of the bacterium is shown in Table 3 .

Table 3. The effect of protecting chlorine-containing imidazoline complexes of NOA.

\begin{tabular}{|c|c|c|c|c|}
\hline \multirow{2}{*}{ Conditional name } & \multirow{2}{*}{$\begin{array}{c}\text { Correlation of } \\
\text { complexes }\end{array}$} & \multicolumn{3}{|c|}{ Concentration of complexes, mq/1 } \\
\hline & & 15 & 75 & 150 \\
\hline \multicolumn{5}{|c|}{ Amount of forming $\mathrm{H}_{2} \mathrm{~S}, \mathrm{mg} / \mathrm{l}$} \\
\hline Chloride of complex I & $1: 1$ & 80 & 40 & - \\
\hline Chloride of complex II & $1: 1$ & - & - & - \\
\hline Medium 1 “Postgate-B” & \multicolumn{4}{|c|}{$24-32$} \\
\hline Medium 2 "Postgate-B" and SRB & \multicolumn{4}{|c|}{275} \\
\hline \multicolumn{5}{|c|}{ Corrosion protection of complexes \% } \\
\hline Chloride of complex I & $1: 1$ & 70,9 & 85,4 & 100 \\
\hline Chloride of complex II & $1: 1$ & 100 & 100 & 100 \\
\hline
\end{tabular}

According to Table 3, when SRB affects on chloride of complex II in correlation 1:1 with concentrations of $15,75,150 \mathrm{mq} / \mathrm{l}$, no
$\mathrm{H}_{2} \mathrm{~S}$ formation is observed because this complex at all concentration displays a $100 \%$ bactericid effect to completely suppress the 
growth of SRB. Chloride of complex I exerts biostate action, and at $75 \mathrm{mg} / \mathrm{l}$ it demonstrates biocide action and suppresses the activity of SRB. At concentration of $150 \mathrm{mg} / \mathrm{l}$ it shows $100 \%$ bactericide effect to suppress the growth of SRB.

Anticorrosion properties of synthesized complexes. The ACM GL was used to study the kinetics of the $\mathrm{CO}_{2}$ corrosion process. The process is carried out at a temperature of 500
${ }^{\circ} \mathrm{C}$, with the participation of an electrode of low-carbon steel C1018. During a 20-hour test, the corrosion current and the loss of metal and corrosion rates (mm/year) were calculated automatically every 15 minutes in the research. The obtained chlorine-containing imidazoline complexes of NOA were tested as corrosion inhibitors at $100 \mathrm{ppm}$. The effect of complex solutions on the $\mathrm{CO}_{2}$ corrosion process is shown in Table 4.

Table 4. Effect of complex solutions on the $\mathrm{CO}_{2}$ corrosion process

\begin{tabular}{|c|c|c|c|c|}
\hline Solution numbers & $\begin{array}{c}\text { Corrosion current, } \\
\mathrm{mA} / \mathrm{c}\end{array}$ & $\begin{array}{c}\text { Corrosion } \\
\text { rate, mm/year }\end{array}$ & $\begin{array}{c}\text { Total } \\
\text { metal }\end{array}$ & $\begin{array}{c}\text { Potential } \\
(\mathrm{mV})\end{array}$ \\
\hline Chloride of complex I & 0.0233 & 0.2702 & 0.0006 & 587.6 \\
\hline Chloride of complex II & 0.0158 & 0.1833 & 0.0007 & 619.9 \\
\hline Without inhibitors & 0.3406 & 3.9474 & 0.0067 & -689.6 \\
\hline
\end{tabular}

At the turn of 20 hours, the effect of corrosion protection of these chlorinecontaining imidazoline complexes of NOA

reached $95.35 \%$ and $93.14 \%$ mass (Fig.5) respectively.

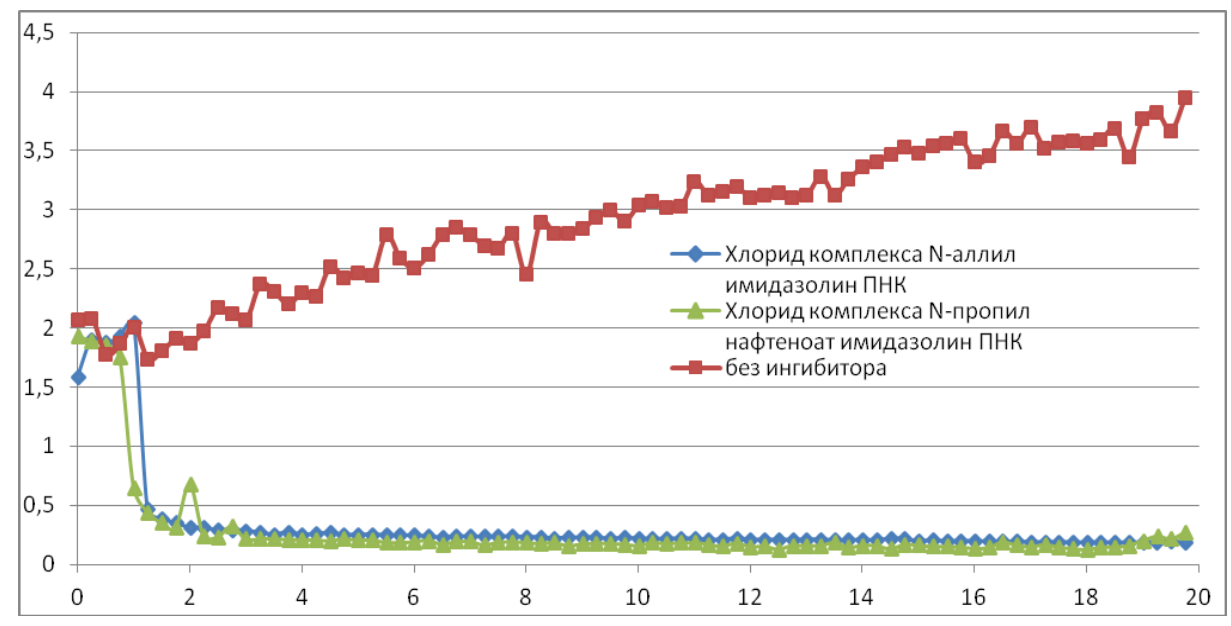

Fig. 5. The influence of chlorine-containing imidazoline complexes of NOA on the corrosion kinetics of $\mathrm{CO}_{2}$ in a $1 \%$ aqueous solution of $\mathrm{NaCl}$ saturated with $\mathrm{CO}_{2}$ at $100 \mathrm{ppm}$.

The effect of chlorine-containing imidazoline complexes of $\mathrm{NOA}$ on $\mathrm{H}_{2} \mathrm{~S}$ corrosion was analyzed as well. The two-phase systems of water: kerosene in 9: 1 ratio was used in the investigation. The water was saturated with $\mathrm{H}_{2} \mathrm{~S}$ to $500 \mathrm{mg} / \mathrm{l}$. The medium was mixed by a magnetic mixer. The experiment lasted for 5 hours. The steel plates for 3 hours. The experiments showed that the best indications proved to be chloride of complex I at a concentration of 5, 10, $15 \mathrm{ppm}$ showing respectively 92, 95.99 and $100 \%$, chloride of complex II at all concentrations showed $100 \%$ protection against $\mathrm{H}_{2} \mathrm{~S}$ 
corrosion which makes it possible to recommend them as an $\mathrm{H}_{2} \mathrm{~S}$ corrosion inhibitor (Tab.5). Table 4 provides data on inhibiting and bactericidal properties

of

Table 4. Comparative analysis of inhibiting and bactericidal properties of complexes

\begin{tabular}{|c|c|c|c|c|c|c|}
\hline \multirow[t]{2}{*}{ Name of complex } & \multicolumn{2}{|c|}{$\begin{array}{l}\text { Corrosion protection } \\
\text { from } \mathrm{H}_{2} \mathrm{~S}\end{array}$} & \multicolumn{2}{|c|}{$\begin{array}{l}\text { Corrosion protection } \\
\text { from } \mathrm{CO}_{2}\end{array}$} & \multicolumn{2}{|c|}{$\begin{array}{l}\text { Influence } \\
\text { on SRB }\end{array}$} \\
\hline & $\begin{array}{c}\text { Min. } \\
\text { consentr } \\
\text { ation } \\
\text { mq/l } \\
\end{array}$ & $\begin{array}{c}\text { Effect } \\
\text { pro } \\
\text { tection } \\
\% \\
\end{array}$ & $\begin{array}{c}\text { Min. } \\
\text { consen- } \\
\text { tration } \\
\mathrm{mq} / \mathrm{l}\end{array}$ & $\begin{array}{c}\text { Min. } \\
\text { consentrat } \\
\text { ion } \mathrm{mq} / \mathrm{l}\end{array}$ & $\begin{array}{c}\text { Effect } \\
\text { pro } \\
\text { tection } \\
\% \\
\end{array}$ & $\begin{array}{c}\text { Min. } \\
\text { consen- } \\
\text { tration } \\
\text { mq/l }\end{array}$ \\
\hline Chloride of complex $\mathrm{N}$-allyl & 5 & 92 & 100 & 95,35 & 15 & 70,9 \\
\hline imidazoline of NOA & 10 & 95,99 & & & 75 & 85,4 \\
\hline (Chloride of complex I) & 15 & 100 & & & 150 & 100 \\
\hline Chloride complex N-propyl & 5 & 100 & 100 & 93,14 & 15 & 100 \\
\hline naphtenate imidazoline of & 10 & 100 & & & 75 & 100 \\
\hline NOA(Chloride of complex II). & 15 & 100 & & & 150 & 100 \\
\hline
\end{tabular}

\section{RESULTS}

The imidazolines NOA obtained on the basis of natural oil acids with diethylenetriamine were synthesized. The chlorine-containing imidazoline complexes of NOA were obtained on the basis of synthesized imidazoline NOA having been tested as inhibitors: 1) with $\mathrm{CO}_{2}$ corrosion (100 ppm) the chlorine-containing imidazoline complexes of NOA protect the metal surface at 93.14 and $95.35 \%, 2$ ) with $\mathrm{H}_{2} \mathrm{~S}$ corrosion (5, $10,15 \mathrm{ppm})$ the chloride of complex $\mathrm{N}$-allyl imidazoline of NOA protects the metal surface respectively at 92, 95.99 and $100 \%$; Chloride complex N-propyl naphtenate imidazoline of NOA (5 ppm) protects the metal surface against $\mathrm{H}_{2} \mathrm{~S}$ corrosion by $100 \%$. The physicochemical characteristics and the effect of the synthesized compounds on the activity of sulfate-reducing bacteria in three concentrations at $30^{\circ} \mathrm{C}$ for 15 days were also studied. It found that the chloride complex Npropyl naphtenate imidazoline of NOA at low concentrations (15ppm) has higher antibacterial properties and can be recommended as a highly effective inhibitor against bio-corrosion of metals.

\section{REFERENCES}

1.Tributsch H., Rojas Chapana J.A. Metal sulfide semiconductor electrochemical mechanisms inducted by bacterial activity. Electrochim. Acta. 2000, vol. 45, pp. 47054716.

2. Miranda E., Bethencourt M., Botana F.J., Cano M.J., Sanchez-Amaya J.M., Corzo A., Olivier B. Biocorrosion of carbon steel alloys by an hydrogentrophic sulphate-reducing bacterium Desulfovibrio capillatus isolated from a Mexican oil field separator. Corrosion Science. 2006, vol. 48, pp. 24172431.

3. Abbasov B.M., Jabrailzade Sh.Z., Mursalov
N.İ. and other. Sulfonous distillates of diesel fuel as corrosion inhibitors and bactericides. Journal of Natural and Technical Sciences. 2010, no. 3 (47), pp. 60-64.

4. Abbasov V.M., Haney M. Abd El-Latef, Aliyeva L.I. et al. Evalution of new complex surfactants based on vegetable oil as corrosion inhibitors for midl steeel in $\mathrm{CO}_{2}$ saturated $1 \%$ NaCI solution. Journal of Materials Physics and Chemistry. 2013, no. 2, pp. 19-26.

5. Abbasov V.M., Rzayeva N.Sh., Talybov A.G. Synthesis and study of sulfate derivative of N-cyclohexylamides of oleic acid as an inhibitors of $\mathrm{CO}_{2}$ corrosion. / 13 th Ibn Sina 
International Conference on Pure and Applied Heterocyclic Chemistry «Heterocyclic Chemistry for Sustainable Future». Hurgada, Egypt, 14-17 february 2015, p. 211.
6.Kuznetsov Y.I. Physio-chemical aspects of the inhibition of corrosion of metals in water governmental solution. Russian Chemical Reviews. 2004, vol. 73, no.1, pp.79-93.

\title{
СИНТЕЗ И ИССЛЕДОВАНИЕ АНТИКОРРОЗИОННЫХ И БАКТЕРИЦИДНЫХ СВОЙСТВ ХЛОРСОДЕРЖАЩИХ ИМИДАЗОЛИНОВЫХ КОМПЛЕКСОВ ПРИРОДНЫХ НЕФТЯНЫХ КИСЛОТ
}

\author{
Н.А. Мамедова, С.А. Мамедханова \\ Азербайджанский Государственный Университет Нефти и Промышленности, \\ Az 1010, г. Баку, пр Азадлыг 20, e-mail: n.a.mamedova@inbox.ru
}

Синтезированы имидазолиновые комплексы, полученные реакцией дистиллированных природных нефтяных кислот (ПНК) с диэтилентриамином (ДЭТА). На основе полученного имидазолина синтезированы хлорсодержашие комплексы ПНК, определены их физико-химические характеристики; строение подтверждено данными ИК и Н'ЯМР спектров. Изучены свойства хлорсодержащих имидазолиновых комплексов ПНК в качестве ингибиторов $\mathrm{H}_{2} \mathrm{~S}-$, $\mathrm{CO}_{2}-u$ биокоррозий. Испытания показали, что при $\mathrm{CO}_{2-}$ u $\mathrm{H}_{2} \mathrm{~S}$ - коррозиях комплексы защищают поверхность металла до 95-100\%. Эффект воздействия синтезированных комплексов на жизнедеятельность сульфатвосстанавливающих бактерий (СВБ) в трех концентрациях при $30^{\circ} \mathrm{C}$ в течение 15 суток выявил, что даже при низких концентрациях комплексы могут быть рекомендованы в качестве высокоэффективных ингибиторов против биокоррозии металлов.

Ключевые слова: коррозия, биоповреждение, дистиллированные природные нефтяные кислоты, имидазолины,ингибиторы, сульфатвосстанавливающие бактерии. 